\title{
Behaviour of Somatic and F-specific Coliphages in Slow Sand Filter
}

\author{
Shinta INDAH***, Hirotaka TANAKA*, Fusheng LI***, Kayako HIROOKA***, Michal \\ ZIELINA*** \\ * Graduate School of Engineering, Gifu University, 1-1 Yanagido, Gifu 501-1193, Japan \\ **Department of Environmental Engineering, Faculty of Engineering, Andalas University, \\ Kampus Limau Manis, Padang 25163, Indonesia \\ ***River Basin Research Center, Gifu University, 1-1 Yanagido, Gifu 501-1193, Japan
}

\begin{abstract}
Behaviour of somatic and F-specific coliphages, as model viruses, in a full-scale slow sand filtration (SSF) treatment plant of Japan was investigated through enumeration with the conventional plaque-forming unit (PFU) and the real-time reverse transcription polymerase chain reaction (RRT-PCR). The results showed that in the effluent of SSF, concentration of coliphages decreased while $\mathrm{Q} \beta$ phage, as a part of F-specific coliphages, was still detected by the RRT-PCR method. The detection of $Q \beta$ may indicate that F-specific RNA phages in the water were mainly derived from human faeces. Moreover, the practice of partial regeneration of the filters did not obviously affect the whole performance of the sand filters in removing coliphages and indicator bacteria (E.coli, total coliforms, general bacteria and heterotrophic bacteria). Furthermore, strong correlations were not obtained among all model viruses and indicator bacteria in the SSF effluent as well as the general water quality indices (turbidity, DOC and UV260). However, a relatively strong correlation was found existent between the indicator bacteria and particle numbers.
\end{abstract}

Keywords: Q $\beta$, slow sand filtration, virus

\section{INTRODUCTION}

Worldwide contamination of surface waters with enteric viruses is of grave health concern since insufficient removal of these pathogens during drinking water treatment might lead to viral infection and gastroenteritis (Ashbolt, 2004; WHO, 2006; Bauer et al., 2011). Slow sand filtration (SSF) has been used as a method of purification for drinking water supplies for over a century, although its application has declined over the last several decades with the introduction of the rapid sand filtration system. However, for developing countries and small communities with limited financial resource and technicians, and even for some developed countries, SSF is still considered as the most appropriate technology for drinking water treatment. Both biological and physical treatments are combined in the process of SSF. The biofilm formed on the sand surface can oxidize ammonia and some taste and odour-causing organic substances; and promote the process of separation for pathogens and turbidity from the raw water (McConnel et al., 1984; Hijnen et al., 2004; Aslan and Cakici, 2007).

A number of studies on the removal of coliphages through SSF have been conducted (Hijnen et al., 2004; Elliott et al., 2008; Bauer et al., 2011) and SSF showed a relatively good performance in reducing coliphages from faecally polluted waters under different experimental conditions. However, most of the studies were conducted based on laboratory-scale experimental set-up and information on the performance of full-scale SSF filters in removing viruses is very limited. On the other hand, for the detection of

Address correspondence to Fusheng Li, River Basin Research Center, Gifu University,

Email: lifs@gifu-u.ac.jp

Received October 23, 2011, Accepted January 4, 2012. 
nano-sized viral species, most of the previous studies employed the conventional plaque-forming unit (PFU) method. However, it is well recognized that the PFU method has the drawbacks of being time-consuming and being largely dependent on culture conditions or nutrient levels. Moreover, the PFU method can only detect infectious viruses. As a new method, the real-time reverse transcription polymerase chain reaction (RRT-PCR) has the merit of being rapid and highly sensitive. This method not only allows investigators to discriminate among microorganisms from different sources, it also allows the detection of extremely small quantities of nucleic acid, hence drawing the attention of water treatment specialists for precise investigation of the microbial behaviour during water treatment (Li et al., 2010). With the RRT-PCR method, the total concentration of microorganisms, both infectious and non-infectious, can also be quantified, suggesting that this method is very attractive for grasping information on the entire behaviour of microorganisms and viruses (Gilbride et al., 2006; Savichtcheva and Okabe, 2006; Zhou et al., 2007).

In this study, using somatic and F-specific coliphages as model viruses, the performance of full-scale SSF in removing viruses was investigated. For this purpose, a full-scale water treatment plant that employs the SSF process for treatment of surface river water was targeted. Water samples before and after filtration by SSF filters under continuous operation for different time lengths (3,30 and 60 days) after partial regeneration were collected over 6 months and subjected to measurement for model viruses. The model viruses were enumerated with the conventional PFU method. On the other hand, for the F-specific RNA Q $\beta$ and MS2 phages, they were quantified by the new RRT-PCR method in order to generate information on the removal performance for the total viruses (infectious and non-infectious) and simultaneously to discriminate the source of contamination from human faeces to animal faeces. In addition to model viruses, indicator bacteria (including E.coli, total coliforms, general and heterotrophic bacteria) and some general water quality indices (including $\mathrm{pH}$, turbidity, DOC, UV260 and particle numbers) were also measured. The relations of the SSF performance in removing model viruses with these bacterial and physico-chemical indices were analyzed as well.

\section{MATERIALS AND METHODS}

\section{Water treatment plant and sample collection}

A full-scale water treatment plant employing SSF filters to produce drinking water from a less polluted river water in Japan (with daily treatment capacity of $140,000 \mathrm{~m}^{3} / \mathrm{d}$ ) were targeted for this study. The depths of sand and gravel packed in each filter were $90 \mathrm{~cm}$ and $35 \mathrm{~cm}$, respectively, and the filtration rate was set at about $4 \mathrm{~m} / \mathrm{d}$. For each filter, after continuous operation for 3 months, partial regeneration was introduced by scraping off the top 1 to $2 \mathrm{~cm}$ dirty sand layer. The influent and effluent water samples, referred hereafter as INF and EFF respectively, were collected monthly from September 2009 to February 2010. For effluent samples, 3 filters operated in parallel for 3, 30 and 60 days, respectively, after regeneration were selected at each sampling time in order to investigate the likely influence of partial regeneration on the behaviour of model viruses. These samples are referred hereafter as $\operatorname{EFF}(3), \operatorname{EFF}(30)$ and $\operatorname{EFF}(60)$. In addition, since quality changes for water above the sand bed (WASB) are highly considerable due to the longer retention time before penetration into the filter bed (about 10 hours), water from the 
surface of WASB was also collected with filters operated for 30 and 60 days after partial regeneration, which are referred hereafter as $\operatorname{WASB}(30)$ and $\operatorname{WASB}(60)$. The sampling points in the SSF filters are shown in Fig.1.

\section{Measurement methods}

For all water samples collected, the concentrations of somatic and F-specific coliphages were determined following the conventional PFU method of ISO 10705-2 (2001) and ISO 10705-1 (2001) using WG5 and WG49 as the host strain, respectively.

The RRT-PCR method was used for the quantification of F-specific RNA Q $\beta$ and MS2. For these purposes, the water samples were concentrated by an adsorption-elution method using an electronegative membrane (Millipore, Tokyo, Japan), followed by further concentration using a Centriprep YM-50 device (Millipore) to obtain a final volume of $700 \mu \mathrm{L}$. From each water sample after concentration, RNA was extracted using the boiling method (heating at $90^{\circ} \mathrm{C}$ for $10 \mathrm{~min}$ and cooling at $4{ }^{\circ} \mathrm{C}$ for $1 \mathrm{~min}$ ) in a thermal cycler (Thermal Cycler Dice Model TP800, Takara Bio Inc., Shiga, Japan). The extracted RNA solution was then added to the PrimeScript ${ }^{\mathrm{TM}}$ RT reagent kit (Takara Bio Inc., Shiga, Japan) for the reverse transcription reaction, which was conducted at $37^{\circ} \mathrm{C}$ for $15 \mathrm{~min}$ and $85^{\circ} \mathrm{C}$ for $5 \mathrm{sec}$, followed by cooling to $4^{\circ} \mathrm{C}$ in the thermal cycler. Finally, the obtained cDNA solution was amplified by a TaqMan probe detection using Premix Ex Taq ${ }^{\mathrm{TM}}$ (Perfect Real Time) (Takara Bio Inc., Shiga, Japan.) for quantification of Q $\beta$; and by the intercalator method with SYBR ${ }^{\circledR}$ Premix Ex Taq ${ }^{\mathrm{TM}}$ II (Perfect Real Time) for MS2. Amplification was conducted at $95^{\circ} \mathrm{C}$ for $30 \mathrm{sec}$ and 40 cycles of $95^{\circ} \mathrm{C}$ for $5 \mathrm{sec}$ and $60^{\circ} \mathrm{C}$ for $30 \mathrm{sec}$ in Thermal Cycler Dice Model TP800 (Takara Bio Inc., Shiga, Japan). The detector response of the RRT-PCR after amplification for each sample was converted to concentration using the calibration curve obtained based on the infectious $\mathrm{Q} \beta$ and MS2 measured by the conventional PFU method. The oligonucleotide sequences of the primers and the probe specific for F-specific RNA Q $\beta$ and MS2 used in the RRT-PCR system for quantification of Q $\beta$ and MS2 are shown in Table 1.

In addition to the above-mentioned model viruses, indicator bacteria including E.coli, total coliforms, and general and heterotrophic bacteria (APHA, AWWA and WEF, 1998), together with the general water quality indices including $\mathrm{pH}$ (HM-20P, TOA-DKK, Japan), dissolved oxygen (TOA-DKK, Japan), turbidity (2100N, HACH, USA), dissolved organic carbon (DOC) (TOC-VWS, Shimadzu Co., Japan), ultraviolet absorbance at $260 \mathrm{~nm}$ (UV260) (UV1600, Shimadzu Co., Japan) and particle numbers (ZVM Hybrid Particle Counter, FUJI ELECTRIC, Japan) were also measured. The measured values for all viral, bacterial and general water quality indices for influent water samples are shown in Table 2.

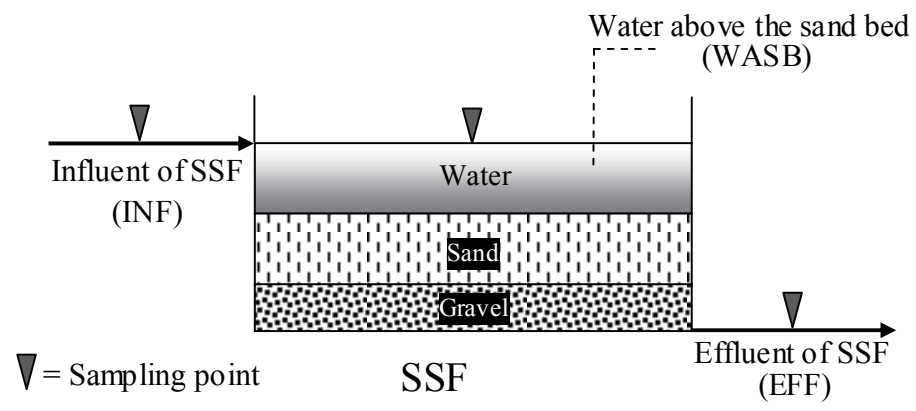

Fig. 1 - Sampling points in the SSF filters. 
Table 1 - Oligonucleotide sequences of the primers and the probe used in the RRT-PCR for quantification of Q $\beta$ and MS2.

\begin{tabular}{lllcc}
\hline Viruses & \multicolumn{1}{c}{ Oligonucleotide sequences } & Positions & References \\
\hline Q $\beta$ & Forward primer & 5'-TCA AGC CGT GAT AGT CGT TCC TC-3' & $41-71$ & \\
& Reverse primer & 5'-AAT CGT TGG CAA TGG AAA GTG C-3' & $187-208$ & Katayama et al., 2002 \\
& Taqman probe & 5'-CGA GCC GCG AAC ACA AGA ATT GA-3' & $147-169$ & \\
MS2 & Forward primer & 5'-CGT TCA CAG GCT TAC AAA GTA ACC T-3' & $1449-1473$ & O'Connell et al., 2006 \\
& Reverse primer & 5'-CCA ACA GTC TGG GTT GCC AC-3' & $1536-1555$ & \\
\hline
\end{tabular}

Table 2 - Ranges and average values of the concentrations of coliphages, indicator bacteria and some general water quality indices during the period of study.

\begin{tabular}{|c|c|c|c|c|c|c|}
\hline \multirow{4}{*}{ Parameter } & \multicolumn{6}{|c|}{ Samples } \\
\hline & \multirow[t]{2}{*}{ SSF influent } & \multicolumn{2}{|c|}{$\begin{array}{c}\text { Water above sand bed (WASB) } \\
\text { after regeneration for }\end{array}$} & \multicolumn{3}{|c|}{ SSF effluent after regeneration for } \\
\hline & & 30 days & 60days & 3 days & 30 days & 60 days \\
\hline & (INF) & $\mathrm{WASB}_{30}$ & WASB $_{60}$ & $\mathrm{EFF}_{3}$ & $\mathrm{EFF}_{30}$ & $\mathrm{EFF}_{60}$ \\
\hline \multicolumn{7}{|l|}{ Coliphages } \\
\hline \multicolumn{7}{|c|}{ Detected by PFU method } \\
\hline \multicolumn{7}{|c|}{ - Somatic (PFU/mL) } \\
\hline - range & $0-0.3$ & $0-0.4$ & $0-0.4$ & $0-0.02$ & ND & $0-0.04$ \\
\hline - average & 0.1 & 0.1 & 0.1 & 0.003 & & 0.001 \\
\hline \multicolumn{7}{|c|}{ - F-spesific (PFU/mL) } \\
\hline - range & $0-0.02$ & $0-0.02$ & ND & ND & ND & ND \\
\hline - average & 0.003 & 0.003 & & & & \\
\hline \multicolumn{7}{|c|}{ Detected by PCR method } \\
\hline - range & $0-17.01$ & $0-1.04$ & $0-525$ & $0-1.79$ & $0-1.8$ & $0-10.5$ \\
\hline - average & 4.7 & 0.2 & 88.2 & 0.5 & 0.5 & 2.3 \\
\hline \multicolumn{7}{|l|}{ - MS2 (PFU/mL) } \\
\hline \multicolumn{7}{|l|}{ - average } \\
\hline \multicolumn{7}{|l|}{$\underline{B a c t e r i a}$} \\
\hline \multicolumn{7}{|l|}{ - E.coli $(\overline{\mathrm{MPN} / \mathrm{mL}})$} \\
\hline - range & $0-7$ & $0-3.3$ & $0-0.8$ & $0-0.2$ & $0-2.3$ & $0-0.5$ \\
\hline - average & 1.7 & 0.7 & 0.1 & 0.03 & 0.4 & 0.08 \\
\hline \multicolumn{7}{|c|}{ - Coliforms (MPN/mL) } \\
\hline - range & $0-7$ & $0-3.3$ & $0-0.8$ & $0-0.2$ & $0-2.3$ & $0-0.5$ \\
\hline - average & 1.7 & 0.7 & 0.1 & 0.03 & 0.4 & 0.08 \\
\hline \multicolumn{7}{|l|}{ - General (CFU/mL) } \\
\hline - range & $6.3-353$ & $12-1097$ & $4-320$ & $2.7-21$ & $4.3-83.7$ & $5.7-20$ \\
\hline - average & 169.3 & 291.8 & 131.2 & 11.4 & 20.8 & 11.4 \\
\hline \multicolumn{7}{|c|}{ - Heterotrophic (CFU/mL) } \\
\hline - range & $8.9 \times 10^{1}-6.5 \times 10^{4}$ & $2.9 \times 10^{1}-1.7 \times 10^{6}$ & $6.9 \times 10^{1}-1.5 \times 10^{5}$ & $5.6 \times 10^{1}-4.1 \times 10^{2}$ & $5.3 \times 10^{1}-2.5 \times 10^{2}$ & $3.0 \times 10^{1}-1.9 \times 10^{3}$ \\
\hline - average & $1.5 \times 10^{4}$ & $2.8 \times 10^{5}$ & $2.6 \times 10^{4}$ & $1.8 \times 10^{2}$ & $1.2 \times 10^{2}$ & $4.2 \times 10^{2}$ \\
\hline \multicolumn{7}{|c|}{ Other water quality parameters } \\
\hline \multicolumn{7}{|c|}{$\overline{-\mathrm{pH}}$} \\
\hline - range & $6.98-7.35$ & $7.08-7.38$ & $6.98-7.36$ & $7.02-7.33$ & $6.99-7.35$ & $6.99-7.34$ \\
\hline - average & 7.22 & 7.25 & 7.22 & 7.19 & 7.2 & 7.22 \\
\hline \multicolumn{7}{|l|}{ - Turbidity (NTU) } \\
\hline - range & $0.15-3.20$ & $0.16-4.31$ & $0.12-4.19$ & $0.07-0.15$ & $0.08-0.21$ & $0.08-0.15$ \\
\hline - average & 1.87 & 2.03 & 1.93 & 0.11 & 0.13 & 0.12 \\
\hline - DOC (mg/L) & & & & & & \\
\hline - range & $0.59-1.05$ & $0.69-1.19$ & $0.59-1.24$ & $0.36-0.67$ & $0.35-0.74$ & $0.36-0.71$ \\
\hline $\begin{array}{c}\text { - average } \\
-\mathrm{UV}_{260}\left(\mathrm{~cm}^{-1}\right)\end{array}$ & 0.81 & 0.87 & 0.95 & 0.54 & 0.62 & 0.56 \\
\hline - range & $0.01-0.05$ & $0.02-0.06$ & $0.01-0.05$ & $0.01-0.03$ & $0.01-0.03$ & $0.01-0.03$ \\
\hline - average & 0.03 & 0.03 & 0.03 & 0.02 & 0.02 & 0.02 \\
\hline - Particle (number/n & & & & & & \\
\hline $\begin{array}{l}(0.5-1) \mu \mathrm{m} \\
\text { - range }\end{array}$ & $3.8 \times 10^{4}-1.2 \times 10^{6}$ & $2.7 \times 10^{4}-9.5 \times 10^{5}$ & $3.9 \times 10^{4}-7.7 \times 10^{5}$ & $1.3 \times 10^{4}-4.3 \times 10^{4}$ & $1.2 \times 10^{4}-6.4 \times 10^{4}$ & $2 \times 10^{4}-2.5 \times 10^{5}$ \\
\hline $\begin{array}{l}\text { - average } \\
(1-3) \mu \mathrm{m}\end{array}$ & $5.4 \times 10^{5}$ & $3.6 \times 10^{5}$ & $2.8 \times 10^{5}$ & $2.7 \times 10^{4}$ & $3 \times 10^{4}$ & $7 \times 10^{4}$ \\
\hline - range & $3.04 \times 10^{3}-9.8 \times 10^{4}$ & $6 \times 10^{3}-6.8 \times 10^{4}$ & $4.6 \times 10^{3}-8.4 \times 10^{4}$ & $6.6 \times 10^{2}-3.2 \times 10^{4}$ & $6.7 \times 10^{2}-1.1 \times 10^{4}$ & $8.3 \times 10^{2}-3.8 \times 10^{3}$ \\
\hline $\begin{array}{l}\text { - average } \\
(3-15) \text { um }\end{array}$ & $3.9 \times 10^{4}$ & $3.1 \times 10^{4}$ & $3.5 \times 10^{4}$ & $7.1 \times 10^{3}$ & $3 \times 10^{3}$ & $1.8 \times 10^{3}$ \\
\hline - range & $8.9 \times 10^{1}-6.5 \times 10^{4}$ & $1.3 \times 10^{2}-1.3 \times 10^{4}$ & $1.6 \times 10^{2}-6.5 \times 10^{3}$ & $6.8 \times 10^{1}-1.2 \times 10^{3}$ & $3.1 \times 10^{1}-3.1 \times 10^{2}$ & $4.4 \times 10^{1}-6.5 \times 10^{2}$ \\
\hline - average & $1.5 \times 10^{4}$ & $4.5 \times 10^{3}$ & $2.7 \times 10^{3}$ & $3.1 \times 10^{2}$ & $1.4 \times 10^{2}$ & $1.9 \times 10^{2}$ \\
\hline
\end{tabular}




\section{RESULTS AND DISCUSSION}

\section{Concentration changes of model viruses and other indices before and after filtration}

The ranges and average values of the concentrations of coliphages, indicator bacteria and general water quality indices in all water samples during the study period are summarized in Table 2. To different extent, UV260, DOC, turbidity and numbers of particles categorized into $0.5-1,1-3$ and $3-15 \mu \mathrm{m}$ in the filtered water decreased as compared to the influent water and the water above the sand bed, indicating that the functions of SSF filters expected generally for removing inorganic and organic impurities were achieved. In regard to the indicator bacteria, significant reductions were found in both general and heterotrophic bacteria; however, for total coliforms and E.coli, a few exceptions were found existent with their concentrations in the filtered water exceeding those in the influent water or the water above the sand bed.

For model viruses, the concentrations of somatic coliphages after filtration decreased significantly and the F-specific coliphages were detected in both influent water and the water above the sand bed, but was not detected at all in the effluent, indicating that this viral species was entirely eliminated within the filter bed. It is well known that the F-specific coliphages are classified into four groups: the genogroup I (MS2-like), the genogroup II (GA-like), the genogroup III (Q $\beta$-like) and the genogroup IV (SP-like). Genogroups I and IV are generally associated with animal faeces and waters contaminated by animal activities, while genogroups II and III indicate predominantly human faecal contamination (Brion et al., 2002; Schaper et al., 2002; Scott et al., 2002; Cole et al., 2003). To discriminate the source of faecal contamination, the RRT-PCR method was performed in this study using MS2 and Q $\beta$ phages as the representatives of animal and human faeces, respectively. In all water samples, MS2 was not detected, which may suggest that the surface river water source was probably not polluted by animal faeces. For $\mathrm{Q} \beta$, however, even if a slight removal could be observed, there were cases that its concentration in the effluent was higher than that in the water before filtration. Detailed discussion on the results of model viruses will be given in the following section.

\section{Seasonal changes of model viruses in water before and after filtration}

The somatic and F-specific coliphages as well as F-specific RNA Q $\beta$ phage concentrations in all water samples collected during a 6-month period of study are displayed in Fig. 2. The negative results are not shown because the data are plotted in log scale. Somatic coliphages in the water samples before filtration were detected in almost all months of the study, which varied from 0.02 to $0.4 \mathrm{PFU} / \mathrm{mL}$; whereas in the effluent, this coliphage species was not detected except for two samples collected in January and November. On the other hand, for the F-specific coliphages, the presence was found only in water before filtration with a concentration of $0.02 \mathrm{PFU} / \mathrm{mL}$, but was not found in water after filtration. The absence of F-specific coliphages in the filtered water may indicate that the SSF can eliminate the risk of human enteric viruses (IAWPRC, 1991).

F-specific coliphages were only detected at a concentration of $0.02 \mathrm{PFU} / \mathrm{mL}$ by the PFU method in two water samples before filtration and were not detected in water after filtration (Fig. 2b). Nevertheless, for $\mathrm{Q} \beta$ detected by the RRT-PCR method, its concentrations ranged from 0.01 to $525 \mathrm{PFU} / \mathrm{mL}$ and from 0.01 to $10.5 \mathrm{PFU} / \mathrm{mL}$ in the water before and after filtration, respectively (Fig. 2c). Since Q $\beta$ is a part of the F-specific 

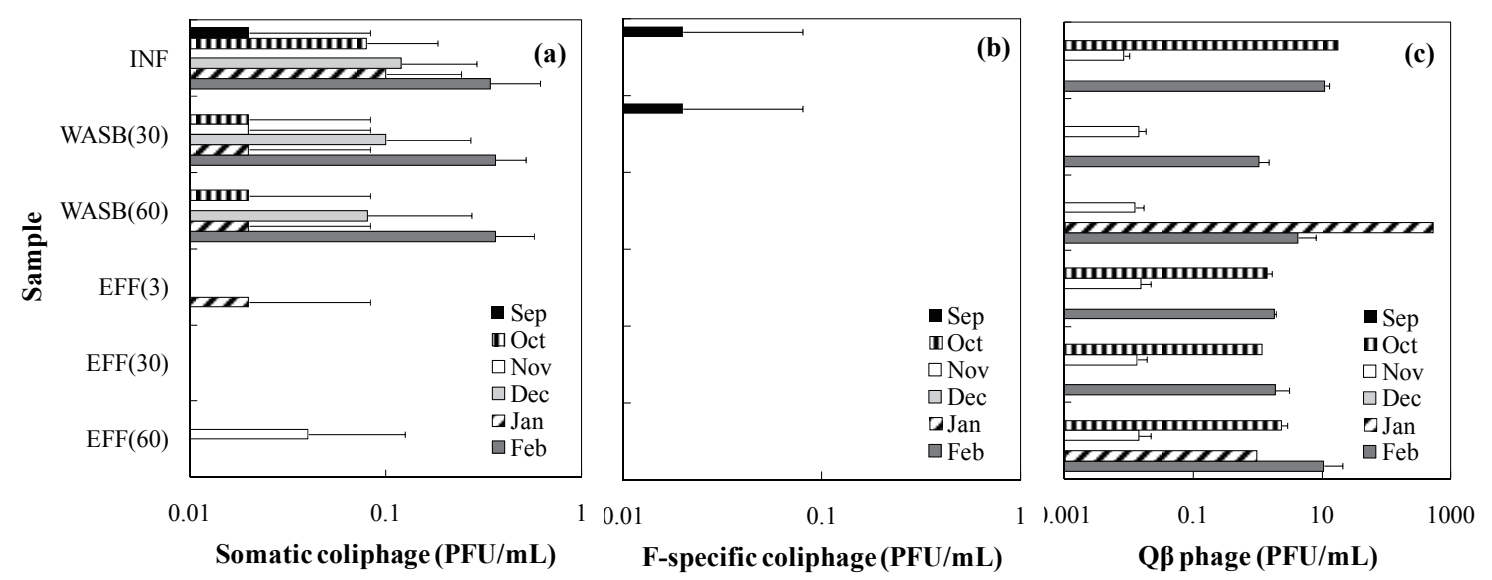

Fig. 2 - Concentrations of (a) somatic and (b) F-specific coliphages and (c) Q $\beta$ in all water samples during the period of study.

coliphages, the frequent detection and presence of relatively higher levels of $\mathrm{Q} \beta$ may indicate that most F-specific coliphages in the river water studied consisted of non-infectious coliphages and they were not satisfactorily removed by SSF filters. The detection of Q $\beta$ may also indicate that F-specific RNA phages in the water were mainly derived from human faeces.

The results of the indicator bacteria of E. coli, total coliforms and general and heterotrophic bacteria measurements are shown in Fig. 3. General decreases in the concentration of the indicator bacteria after filtration were observed throughout the period of study indicating the efficacy of slow sand filters for controlling microbiological contaminants, as reported (Hijnen et al., 2007). Hijnen et al. (2004) observed the positive effect of biofilm (schmutzdecke) at the top few millimetres of the sand layer on the elimination of bacteria and protozoan oocysts, because straining was an important removal mechanism for these organisms. However, the elimination of viruses was not affected by the biofilm, because of their small size. The lower removal rate for $\mathrm{Q} \beta$ as shown in Fig. 2c may support the observation of Hijnen et al.

On the other hand, the general and heterotrophic bacteria were still observed in samples after filtration (Fig. 3b and 3c). These bacteria may be a part of the total bacteria in the influent water that were not captured within the filters but, at the same time, they may also come from the biofilm detached during filtration. To differentiate these two possibilities, analysis of the microbial community structure in both raw water and the filtered water is considered necessary, which will be conducted in the succeeding studies.

Comparison of water samples collected from filters operated continuously for 3, 30 and 60 days after regeneration showed no remarkable differences for all viral and bacterial indices investigated. This indicated that the practice of regeneration of the filters by scraping off the top 1 to $2 \mathrm{~cm}$ of dirty sand layer did not obviously affect the whole performance of the sand filters with a packed depth of $90 \mathrm{~cm}$. 

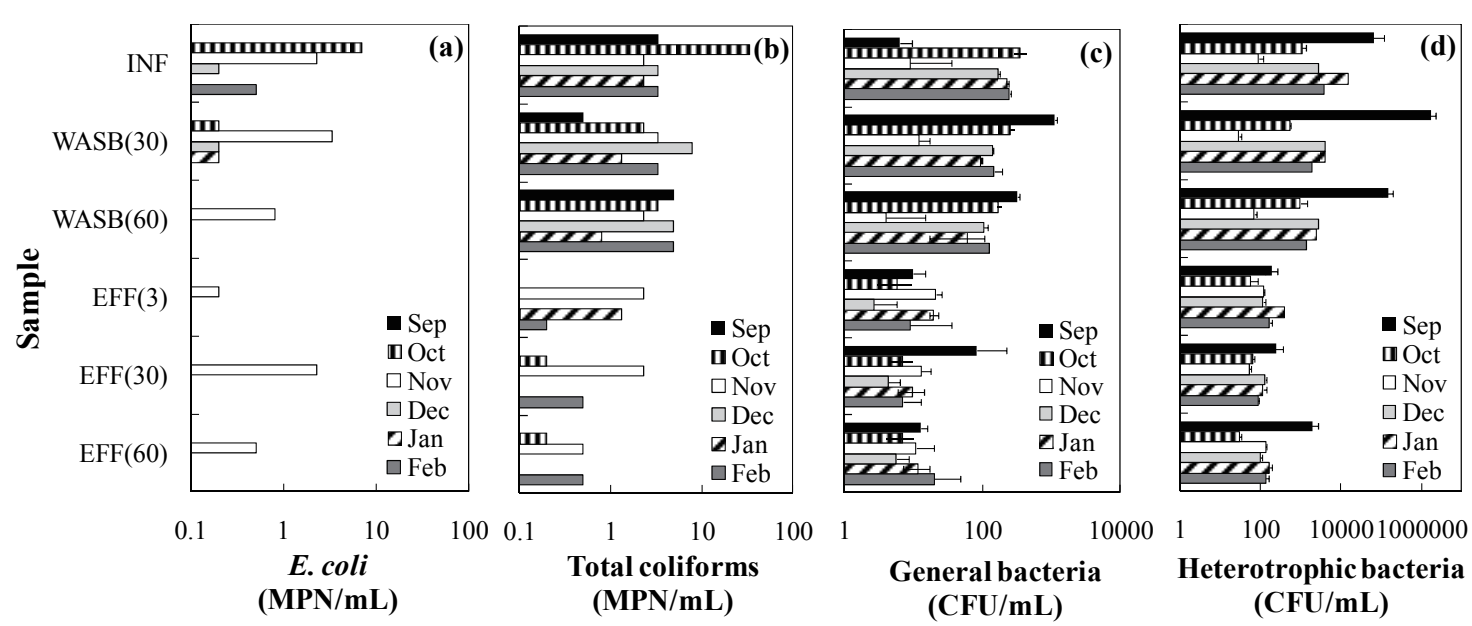

Fig. 3 - Concentrations of (a) E.coli, (b) total coliforms, (c) general bacteria and (d) heterotrophic bacteria in all water samples during the period of study.

\section{Relations of coliphage concentrations with the other parameters}

Correlation analysis was performed with somatic coliphages and $\mathrm{Q} \beta$, because F-specific coliphages data were not sufficient for the analysis. Weak correlations of somatic coliphages and $\mathrm{Q} \beta$ with E.coli $(\mathrm{R}=0.31-0.44)$, total coliforms $(\mathrm{R}=0.36-0.52)$, general bacteria $(R=0.33-0.39)$ and heterotrophic bacteria $(R=0.35-0.57)$ in filtered water samples were observed (Fig. 4). Moreover, there was no significant correlation between somatic coliphages and $\mathrm{Q} \beta$ concentrations with the general water quality indices of turbidity $(\mathrm{R}=0.44-0.53)$, DOC $(\mathrm{R}=0.01-0.25)$ and UV260 $(\mathrm{R}=0.31-$ $0.35)$.

Furthermore, relations of coliphages with particle numbers divided into the size ranges of $0.5-1 \mu \mathrm{m}, 1-3 \mu \mathrm{m}$ and $3-15 \mu \mathrm{m}$ were also analyzed in water samples after filtration. Strong correlations were not revealed $(R=0.04-0.44)$. The relationships between the indicator bacteria and the particle numbers were evaluated as well. The correlation coefficients based on the bacteria and the particle size fraction for total coliforms, general and heterotrophic bacteria were in the ranges of $0.56-0.68,0.73$ 0.75 and $0.56-0.67$, respectively, as shown in Fig. 5. The strongest correlation was found existing between the indicator bacteria and particle number in size range of 1 - 3 $\mu \mathrm{m}$ suggesting that the behaviour of bacteria is similar to the behaviour of particles in size range of $1-3 \mu \mathrm{m}$. 

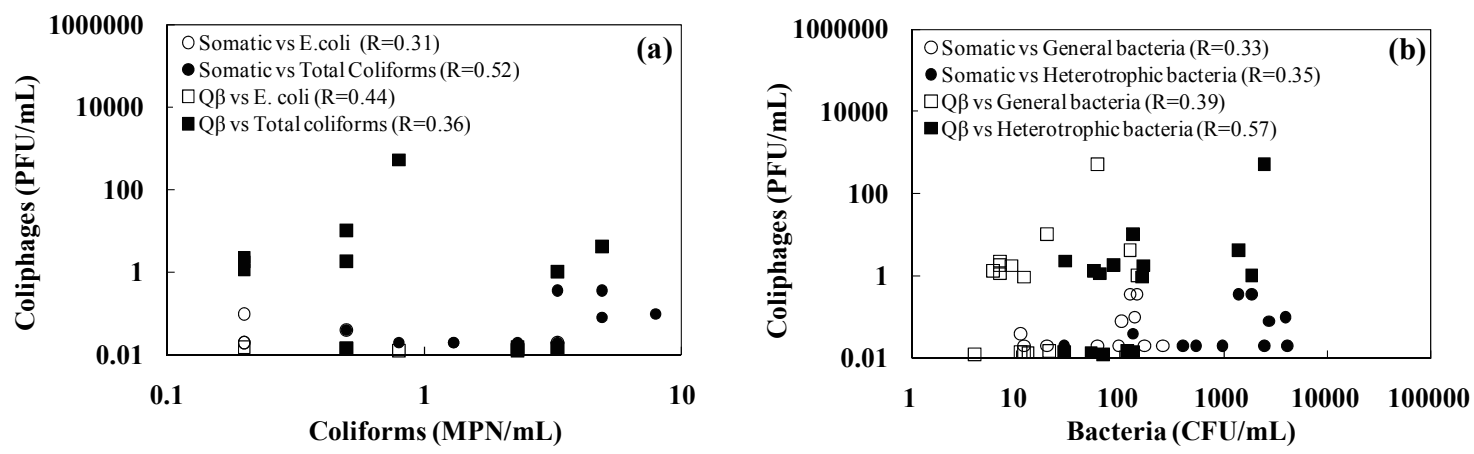

Fig. 4 - Relationships between somatic coliphage and Q $\beta$ phage concentrations with (a) coliforms and (b) bacteria.
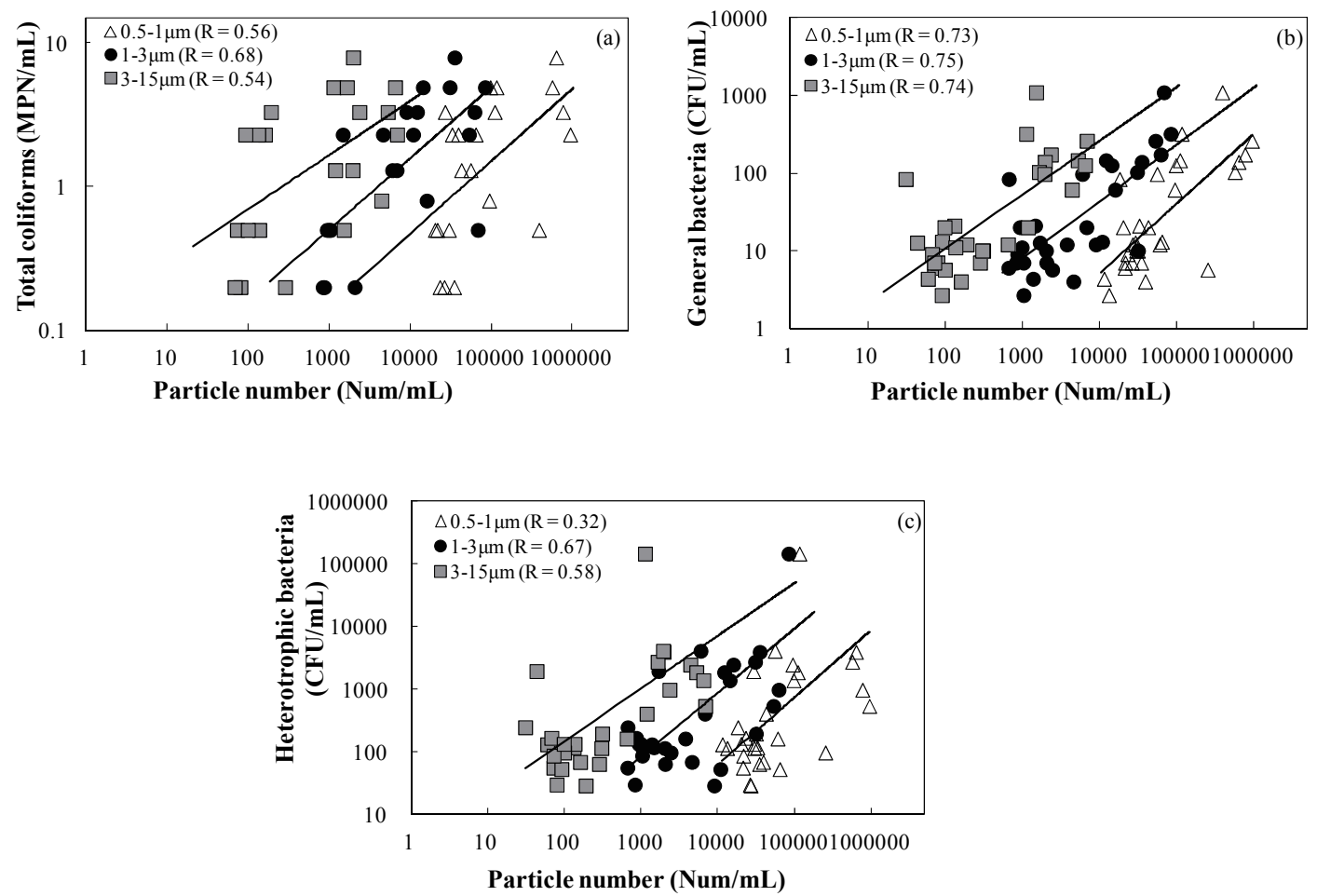

Fig. 5 - Relationships between particle numbers with (a) total coliforms, (b) general bacteria and (c) heterotrophic bacteria. 


\section{CONCLUSION}

Using somatic and F-specific coliphages as model viruses, the performance of a full-scale SSF in removing viruses was investigated through enumeration with the conventional PFU and RRT-PCR methods and was discussed along with the results of indicator bacteria as well as some general water quality indices. The results demonstrated that the infectious somatic and F-specific coliphages measured by PFU method were not detected in the effluent of SSF during the period of study, relatively similar to the detection of their host, E. coli. In the contrary, Q $\beta$ phage was still detected by RRT-PCR method in effluent samples, as well as the total phages, including both the infectious and non-infectious ones. The detection of $\mathrm{Q} \beta$ may indicate that F-specific RNA phages in the water were mainly derived from human faeces. The practice of regeneration of the filters by scraping off the top 1 to $2 \mathrm{~cm}$ of dirty sand layer did not obviously affect the whole performance of the sand filters in removing coliphages and indicator bacteria. Furthermore, no strong correlation was obtained between the concentration of somatic coliphages with the indicator bacteria, as well as with the general water quality indices. However, a relatively strong correlation was found to exist between the indicator bacteria and particle numbers.

\section{REFERENCES}

APHA-AWWA-WEF (1998) Standard methods for the examination of water and wastewater, 20th ed. APHA, New York, USA.

Ashbolt N. (2004) Microbial contamination of drinking water and disease outcomes in developing regions. Toxicol., 198, 229-238.

Aslan S. and Cakici H. (2007) Biological denitrification of drinking water in a slow sand filter. J. Hazard. Mat., 148, 253-258.

Bauer R., Dizer H., Graeber I., Rosenwinkel K. H. and Lo'pez-Pila J. M. (2011) Removal of bacterial faecal indicators, coliphages and enteric adenoviruses from waters with high faecal pollution by slow sand filtration. Water Res., 45, 439-452.

Brion G. M., Meschke J. S. and Sobsey M. D. (2002) F-specific RNA coliphages: occurrence, types, and survival in natural waters. Water Res., 36, 2419-2425.

Cole D., Long S. C. and Sobsey M. D. (2003) Evaluation of $\mathrm{F}^{+}$RNA and DNA coliphages as source-specific indicators of faecal contamination in surface waters. Appl. Environ. Microbiol., 69, 6507-6514.

Elliott M. A., Stauber C. E., Koksal F., Digiano F. A. and Sobsey M. D. (2008) Reductions of E. coli, echovirus type 12 and bacteriophages in an intermittently operated household-scale slow sand filter. Water Res., 42, 2662-2670.

Gilbride K. A., Lee D. Y. and Beaudette L. A. (2006) Molecular techniques in wastewater: Understanding microbial communities, detecting pathogens, and real-time process control. J. Microbiol. Met., 50, 1-20.

Hijnen W., Schijven J., Bonne P., Visser A. and Medema G. (2004) Elimination of viruses, bacteria and protozoan oocysts by slow sand filtration. Water Sci. Technol., 50 (1), 147-154.

Hijnen W., Dullemont Y. J., Schijven, J., Hannzans-Brouwer A. J., Rosielle M. and Medema G. (2007) Removal and fate of Cryptosporidium parvum, Clostridium perfringens and small-sized centric diatoms (Stephanodiscus hantzschii) in slow sand filters. Water Res., 41, 2151-2162. 
IAWPRC Study Group on Health Related Water Microbiology. (1991) Bacteriophages as model viruses in water quality control. Water Res., 25, 529-545.

Katayama H., Shimazaki A. and Ohgaki S. (2002) Development of virus concentration method using negatively charged membrane by alkaline elution after acid rinse. $J$. Japan Soc. Water Environ., 25, 469-475 (in Japanese).

Li F. S., Yoshimura C., Tsubouchi Y. and Li W. (2010) Real-time PCR method based investigation of the removal of microbes by the conventional rapid sand filtration system. Water Supply and Water Quality-present issues, pp.449-456, PZITS, Poznan, Poland.

McConnell L. K., Sims R. C. and Barnet B. B. (1984) Reovirus removal and inactivation by slow-rate sand filtration. Appl. Environ. Microbiol. Act., 818-825.

O’Connell K. P., Bucher J. R., Anderson P. E., Cao C. J., Khan A. S., Gostomski M. V., Valdes J. J. (2006) Real time fluorogenic reverse transcription-PCR assays for detection of bacteriophage MS2. Appl. Environ. Microbiol., 72, 478-483.

Savichtcheva O. and Okabe S. (2006) Alternative indicators of faecal pollution: Relations with pathogens and conventional indicators, current methodologies for direct pathogen monitoring and future application perspectives. Water Res., 43, 2463-2476.

Schaper M., Jofre J., Uys M. and Grabow W. O. K. (2002) Distribution of genotypes of F-specific RNA bacteriophages in human and non-human sources of faecal pollution in South Africa and Spain. J. Appl. Microbiol., 92, 657-667.

Scott T. M., Rose J. B., Jenkins T. M., Farrah S. R. and Lukasik J. (2002) Microbial source tracking: current methodology and future directions. Appl. Environ. Microbiol., 68, 5796-5803.

WHO (2006) Viral pathogens. In: Guidelines for Drinking Water Quality, pp. 247-259, WHO, Geneva, Switzerland.

Zhou W., Kageyama K., Li F. S. and Yuasa A. (2007) Monitoring of microbiological water quality by real-time PCR. Environ. Technol., 28(5), 545-553. 